https://nv.nltu.edu.ua

https://doi.org/10.36930/40300208

$@$ Correspondence author

Article received $26.02 .2020 \mathrm{p}$.

O. I. Lialin

Article accepted 04.06.2020 p.

o_lyalin@ukr.net

UDC $630 * 232.329: 582.632 .2$

\author{
О. І. Лялін 1, О. М. Тарнопільська ${ }^{2}$, Л. І. Ткач1, С. І. Мусієнко ${ }^{2}$, В. В. Бондаренко \\ ${ }^{1}$ Харківський начіональний університет міського господарства ім. О. М. Бекетова, м. Харків, Украӥна \\ ${ }^{2}$ Украйнський ордена "Знак пошани" науково-дослідний інститут лісового господарства і агролісомеліорації ім. Г. М. \\ Висоиького, м. Харків, Україна
}

\title{
СХОЖІСТЬ, ЗБЕРЕЖУВАНІСТЬ І СТАН СІЯНЦІВ СОСНИ ЗВИЧАЙНОЇ (PINUS SYLVESTRIS L.), ВИРОЩЕНИХ У КОНТЕЙНЕРАХ
}

На базі двох підприємств Харківського обласного управління лісового та мисливського господарства Державного агентства лісових ресурсів України, а саме ДП "Чугуєво-Бабчанське ЛГ" та "Вовчанське ЛГ" в умовах Лівобережного Лісостепу України визначено грунтову схожість сіянців сосни звичайної у контейнерах із різним складом субстрату. Досліджено та узагальнено значення збереженості та життєвого стану сіянців з урахуванням впливу складу субстрату коренезакриваючої грудки контейнера. Дослідним шляхом проаналізовано вісім варіантів субстратів: чотири двокомпонентних торфовмісних та чотири трикомпонентних тирсо-перегноєвмісних. Встановлено комплексну перевагу над контролем за названими вище біометричними показниками варіантів із використанням торфу з базовим грунтом в субстраті Тф : Г $-1: 1$ та найбільшою мірою варіанта з використанням грунту, перегною й тирси у пропорціях частин $6: 3: 1$. Результати досліджень із визначення оптимального складу субстрату для вирощування сіянців сосни звичайної із закритою кореневою системою підтвердили високі показники схожості, отримані у варіантах з використанням трикомпонентних сумішей перегною, тирси та темно-сірого опідзоленого середньо суглинкового лісового грунту на лесах. Серед випробуваних субстратів при об'ємі контейнера $500 \mathrm{~cm}^{3}$ за комплексом переваг за досліджуваними показниками схожості, збережуваності та стану торфовмісний варіант із

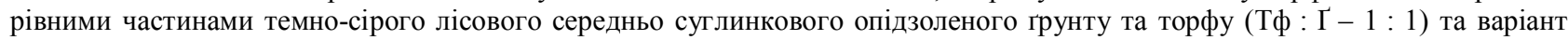
трикомпонентної суміші $Г: П: T-6: 3: 1 €$ найбільш збалансованими за основними грунтовими параметрами та найбільш оптимальними 3 досліджуваних для продуктивного росту сіянців сосни звичайної із закритою кореневою системою. Темносірі лісові опідзолені середньо суглинкові грунти на лесах за рівнем потенційної родючості є одними 3 найродючіших грунтів України. Їх формування відбувалося під достатньо розрідженими широколистяними лісами 3 добре розвиненим трав'яним покривом на важко глинистих карбонатних лесах. Поєднання таких факторів грунтоутворення, як наявність значної кількості високо зольного органічного опаду, а також материнської породи, насиченої кальцієм та глинистими частками, надає темно-сірим опідзоленим грунтам високої поживної здатності.

Ключові слова: сосна звичайна; субстрат; закрита коренева система; грунтова схожість, стан сіянців.

Вступ. Для забезпечення ефективної реалізації робіт 3 лісовідновлення потрібно вирощувати достатню кількість сіянців високої якості головних лісотвірних порід - сосни звичайної та дуба звичайного. Переваги сіянців, вирощених із закритою кореневою системою, над сіянцями, вирощеними 3 відкритою кореневою системою, полягають у відсутності потреби тимчасового прикопування на лісокультурній площі, зменшенні травмування рослин під час транспортування та пересаджування в культури, у можливості подовження періоду створення лісових культур, внесення добрив, воло- гонакопичувачів та інших речовин до кожної рослини в необхідних нормах витрати. Водночас, оптимальні склад субстрату і тривалість вирощування сіянців сосни у контейнерах досліджені недостатньо. Актуальним $\epsilon$ також визначення тривалості збереження позитивного ефекту використання сіянців із закритою кореневою системою в перші роки вирощування лісових культур.

Аналіз літературних джерел. Лісові екосистеми розглядають передусім як головний компонент біосфери, що спроможний стабілізувати, відновлювати та поліпшувати іï природну рівновагу. Вирішення проблем

Інформація про авторів:

Лялін Олександр Іванович, канд. с.-г. наук, доцент, кафедра лісового та садово-паркового господарства. Email: o_lyalin@ukr.net; https://orcid.org/0000-0002-8921-3605

Тарнопільська Оксана Михайлівна, канд. с.-г. наук, ст. наук. співробітник, лабораторія лісівництва. Email: tarnoks@ukr.net; https://orcid.org/0000-0002-4810-8892

Ткач Людмила Іванівна, канд. с.-г. наук, доцент, кафедра лісового та садово-паркового господарства. Email: tkachly@i.ua; https://orcid.org/0000-0002-7790-5911

Мусієнко Сергій Іванович, канд. с.-г. наук, ст. наук. співробітник, лабораторія лісівництва. Email: musienkosergij_les@ukr.net; https://orcid.org/0000-0002-6581-2670

Бондаренко Віра Володимирівна, мол. нак. співробітник, лабораторія лісівництва. Email: bond.vera1601207@gmail.com; https://orcid.org/0000-0001-8187-5519

Цитування за ДСтУ: Лялін О. І., Тарнопільська О. М., Ткач Л. І., Мусієнко С. І., Бондаренко В. В. Схожість, збережуваність і стан сіянців сосни звичайної (Pinus sylvestris L.), вирощених у контейнерах. Науковий вісник НЛТУ України. 2020, т. 30, № 2. C. $44-48$.

Citation APA: Lialin, O. I., Tarnopilska, O. M., Tkach, L. I., Musienko, S. I., Bondarenko, V. V. (2020). Germination, survival rate and health of scots pine (Pinus sylvestris L.) grown in containers. Scientific Bulletin of UNFU, 30(2), 44-48. https://doi.org/10.36930/40300208 
лісовикористання та відновлення лісів в Україні, що спирається на принципи сталого розвитку, набуває важливого загальнодержавного значення. Ліси України $є$ вагомим фактором, що стабілізують на певному рівні функціональну організацію природних екосистем, посилюють їх стійкість до антропогенного навантаження і негативної зміни клімату [10].

До головних проблем відтворення лісів у контексті сталого розвитку галузі належать низькі обсяги лісорозведення та якісного лісовідновлення. Перше віддаляє досягнення науково обгрунтованої лісистості окремих регіонів країни, а друге, особливо штучне, навіть за умов наявних науково обгрунтованих рекомендацій не завжди забезпечує якісне лісовідновлення. Особливо це відчувається під час відтворення біологічно стійких лісових ценозів, максимально наближених за складом і формою до деревостанів корінних типів лісу [8].

Втілення робіт з лісовирощування потребує відповідного фінансового та матеріального забезпечення. Насамперед виникає необхідність впровадження сучасних підходів і технологій для забезпечення лісокультурних робіт високоякісним насінням і стандартним садивним матеріалом. Саме це визначає не тільки успішність росту лісових культур, а й значною мірою зумовлює продуктивність та біологічну стійкість майбутніх насаджень. Майже скрізь виробництво садивного матеріалу iз закритою кореневою системою (далі - СМ ЗКС), як більш технологічне, витісняє традиційну технологію виробництва садивного матеріалу у неконтрольованому середовищі з незахищеною кореневою системою. Використання СМ ЗКС дало змогу нашим закордонним колегам (Швеція, Фінляндія, Німеччина та ін.) не тільки істотно розширити терміни садіння лісових культур, що особливо актуально для України (насамперед для Степу i Лісостепу зі стислими оптимальними весняними термінами створення культур), а й наблизити практично до $100 \%$ приживлюваність садивного матеріалу на лісокультурних площах $[1,3,9]$

Об'єкт дослідження - грунтова схожість сіянців сосни звичайної у контейнерах із різним складом субстрату.

Предмет дослідження - методи і засоби визначення схожості, збережуваності та стану сіянців сосни звичайної (pinus sylvestris 1.), вирощених у контейнерах.

Метою дослідження є вивчення переваг та недоліків вирощування садивного матеріалу сосни в контейнерах.

Основним завданням дослідження є узагальнення значення збереженості та життєвого стану сіянців з урахуванням впливу складу субстрату коренезакриваючої грудки контейнера.
Наукова новизна роботи полягає у тому, що вперше були вивченні перспективні методи вирощування садивного матеріалу одної із головних лісотвірних порід України із застосуванням різних грунтових субстратів.

Практична значущість отриманих результатів полягає у тому, що визначені оптимальні субстрати для вирощування сіянців сосни звичайної в контейнерах дають змогу значно підвищити тї продуктивність та стійкість вирощуваних насаджень.

Матеріали і методи дослідження. Переваги використання СМ ЗКС неодноразово доведені у багатьох публікаціях вітчизняних та закордонних дослідників [4, $9,11]$. У виконаних дослідах використано жорсткий контейнер (типу "грудка") - заввишки 140 мм, середнім діаметром у верхній частині 70 мм, корисним об'ємом $500 \mathrm{~cm}^{3}$. Дно кожного контейнера перфоровано отвором діаметром 6-7 мм для виходу надлишкової вологи від атмосферних опадів. Технологію вирощування, методи та матеріали, які ми використали, детально описано та обгрунтовано у попередніх публікаціях $[5,6,7]$. Характерною особливістю $\epsilon$ те, що сіянці у контейнерах весь час їх вирощування перебували на відкритих полігонах 3 налагодженим трикратним впродовж тижня зрошенням у нормі витрати 10 л/ $\mathrm{M}^{2}$.

Відомо, що внутрішня енергія насіння сосни, а саме життєздатність зародка та достатня кількість поживних речовин ендосперму, а також температура та вологість субстрату забезпечують його проростання, а подальший ріст прямо залежить від вологості та поживності субстрату. Тому метою наших досліджень стало визначення ступеня впливу складу субстрату контейнера на показники схожості насіння, на якісну збережуваність сіянців під час їх вирощування у контейнерах до моменту їх використання. Під час проведення досліджень ми випробовували різний склад субстрату, у складі якого містився низинний, багатий на поживні речовини, торф (Тф), торф'яні таблетки ("Джиффі-7" 30 мм) та суміші грунту (Г), перегною (П) й тирси хвойних порід (Т) 3 різним співвідношенням.

Результати дослідження. Аналіз результатів трьохрічних досліджень проведено згідно з відповідними методиками [2] і наведено у табл. 1. За результатами дослідження встановлено, що достовірно $(\mathrm{P}<0,001)$ найвищі показники схожості насіння сосни, а саме 95,6 \%, отримали у варіанті субстрату зі застосуванням торф'яних таблеток "Джиффі-7". Встановлене значення достовірно $(\mathrm{P}<0,001)$ перевершило значення схожості контрольного варіанта субстрату на $18,3 \%$. За контроль у ролі субстрату контейнера було обрано варіант 3 темно-сірим опідзоленим середньо суглинковим лісовим грунтом на лесах - "Грунт (контроль)".

Табл. 1. Схожість насіння сосни звичайної у контейнерах з різним складом субстрату, \%

\begin{tabular}{|c|c|c|c|c|c|c|}
\hline \multirow{2}{*}{ Варіант } & \multicolumn{2}{|c|}{ Перший рік досліджень } & \multicolumn{2}{|c|}{ Другий рік досліджень } & \multicolumn{2}{|c|}{ Третій рік досліджень } \\
\hline & $x \pm S x$ & $t$ & $x \pm S x$ & $t$ & $x \pm S x$ & $t$ \\
\hline Грунт (контроль) & $76,4^{ \pm 1,59}$ & - & $77,1^{ \pm 2,12}$ & - & $78,4^{ \pm 2,38}$ & - \\
\hline Тф: Г-1:1 & $77,1^{ \pm 2,48}$ & 0,2 & $84,7^{ \pm 2,10}$ & 1,9 & $91,4^{ \pm 2,29}$ & 3,6 \\
\hline Тф : Г-1:2 & $79,2^{ \pm 1,92}$ & 0,7 & $81,3^{ \pm 2,32}$ & 1,0 & $84,6^{ \pm 2,11}$ & 1,6 \\
\hline $\mathrm{T} \phi: \Gamma-2: 1$ & $92,1^{ \pm 2,36}$ & 4,3 & $93,4^{ \pm 2,29}$ & 4,6 & $93,5^{ \pm 2,21}$ & 4,3 \\
\hline Джиффі-7 & $96,5^{ \pm 2,31}$ & 5,9 & $92,8^{ \pm 2,21}$ & 4,4 & $97,6^{ \pm 2,41}$ & 5,9 \\
\hline$\Gamma: \Pi: \mathrm{T}-1: 1: 1$ & $69,6^{ \pm 1,83}$ & 1,5 & $68,9^{ \pm 1,98}$ & 1,8 & $71,6^{ \pm 1,89}$ & 1,6 \\
\hline Г:П $\Pi: \mathrm{T}-4: 4: 2$ & $78,5^{ \pm 1,89}$ & 0,5 & $78,9^{ \pm 2,48}$ & 0,4 & $74,6^{ \pm 1,17}$ & 0,9 \\
\hline Г:П:Т $-5: 4: 1$ & $81,4^{ \pm 2,23}$ & 1,2 & $82,1^{ \pm 1,87}$ & 1,2 & $80,1^{ \pm 2,32}$ & 0,4 \\
\hline Г:П:Т $-6: 3: 1$ & $80,2^{ \pm 2,42}$ & 0,9 & $80,2^{ \pm 2,42}$ & 0,8 & $79,7^{ \pm 1,96}$ & 0,3 \\
\hline
\end{tabular}

Примітки: $t_{0,001}=3,3 ; t_{0,01}=2,6 ; t_{0,05}=2,0 ; t_{0,1}=1,7$. 
Iз випробуваних торфовмісних варіантів найвищу схожість на рівні 93,0 \% встановлено у варіанті Тф : Г$2: 1$. Від попереднього варіанта значення істотно не відрізнялося, але істотно (на $15,7 \%$ ) і достовірно (P $<0,001)$ перевершувало значення контрольного варіанту. Найменшу схожість насіння сосни (70,0 \%) визначено у варіанті використання рівних частин грунту, перегною та тирси (Г : П: Т - $1: 1: 1)$. Середній показник схожості за всіма варіантами становив 81,2; 82,2 та 83,5 \% відповідно за роками досліджень, що загалом підтверджує придатність субстратів та обрану технологію, проте остання може бути вдосконаленою.

Порівняння середніх за три роки даних щодо схожості насіння сосни у варіантах субстрату свідчить, що в разі використання субстратів, що містять торф, цей показник становив 86,4 \% без урахування Джиффі-7 та $88,7 \%$ - 3 урахуванням Джиффі-7, а в разі використання субстратів з умістом таких складників, як грунт-перегній-тирса $-77,2 \%$ (рис. 1).

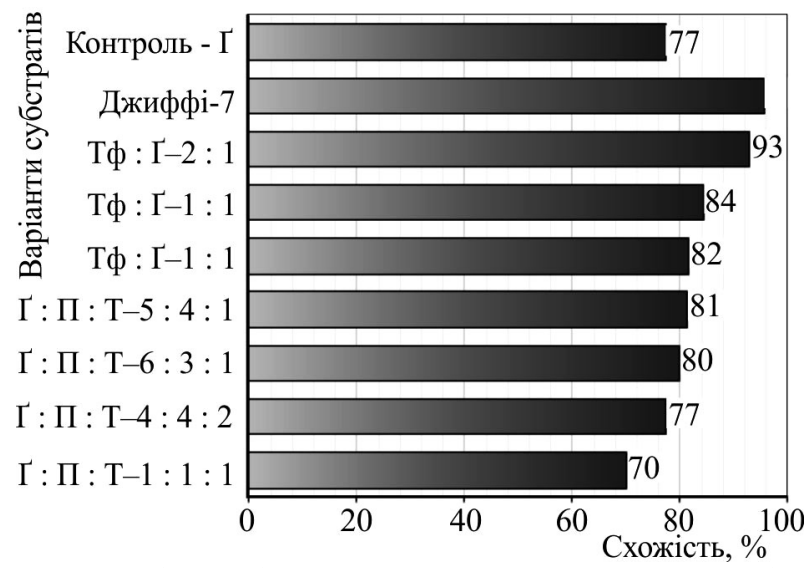

Рис. 1. Схожість насіння сосни звичайної у контейнерах 3 різним складом субстрату (середнє за три роки досліджень)
Схожість у варіанті Тф : Г - $1: 1$ виявилася достовірно більшою $(\mathrm{P}<0,1)$, ніж у варіанті, де торф становив третину об'єму субстрату (84,4 і $81,7 \%$ відповідно). Збільшення вмісту торфу у субстраті (до двох третин) сприяло підвищенню схожості насіння. Цей показник становив 93,0\%, тобто мав найбільше значення з усіх варіантів, за винятком варіанта з Джиффі-7.

У варіантах із вмістом перегною і тирси у складі субстрату схожість насіння була найменшою (70,0 \%) у варіанті співвідношення Г : П: Т - $1: 1: 1$. Цей показник недостовірно поступався контрольному варіанту та трикомпонентній суміші Г : П : Т - $4: 4: 2$.

Показник збережуваності визначили навесні наступного року після сівби. Збережуваність сіянців у контейнерах оцінювали наприкінці II декади березня, як виражену у відсотках частку збережених рослин від загальної кількості сходів за варіантами (табл. 2).

У середньому за варіантами збережуваності сіянців у контейнерах за роками досліджень відповідно становила 57,5; 63,1 і 68,6 \%. Зростання показника за роками відзначено також на контролі та в усіх варіантах досліду, що можна пояснити певним набутим досвідом щодо вирощування садивного матеріалу у контейнерах - підвищення якості підготовки субстрату для контейнерів, щільності субстрату контейнерів, здійснення мульчування посівів та доглядів до і після появи сходів.

В усі роки проведення експериментів найвищого значення збережуваності сіянців (у середньому 78,8 \%) мав контрольний варіант. На аналогічному рівні значення збережуваності сіянців встановлено й у варіанті використання Джиффі-7 (у середньому 79,3\%), що $є$ статистично недостовірно, але вищим показником (рис. 2). Середнє значення показника збережуваності у варіантах 3 використанням торфу становило 66,7 \%, у варіантах використання перегною й тирси $-64,6 \%$.

Табл. 2. Збережуваність сіянців сосни звичайної у контейнерах з різним складом субстрату, \%

\begin{tabular}{|c|c|c|c|c|c|c|}
\hline \multirow{2}{*}{ Варіант } & \multicolumn{2}{|c|}{ Перший рік досліджень } & \multicolumn{2}{|c|}{ Другий рік досліджень } & \multicolumn{2}{|c|}{ Третій рік досліджень } \\
\hline & $x \pm S x$ & $t$ & $x \pm S x$ & $t$ & $x \pm S x$ & $t$ \\
\hline Грунт (контроль) & $76,4^{ \pm 6,51}$ & - & $78,3^{ \pm 7,07}$ & - & $81,6^{ \pm 7,79}$ & - \\
\hline Тф: Г-1: 1 & $64,8^{ \pm 4,81}$ & 2,5 & $68,6^{ \pm 5,89}$ & 2,2 & $70,2^{ \pm 6,75}$ & 2,7 \\
\hline Тф: $Г-1: 2$ & $67,2^{ \pm 5,21}$ & 2,0 & $72,5^{ \pm 6,23}$ & 1,3 & $77,6^{ \pm 6,89}$ & 1,0 \\
\hline $\mathrm{T} \phi: \Gamma-2: 1$ & $58,3^{ \pm 4,86}$ & 3,9 & $59,2^{ \pm 4,98}$ & 4,1 & $61,6^{ \pm 5,98}$ & 4,4 \\
\hline Джиффі-7 & $78,2^{ \pm 6,42}$ & 0,4 & $79,1^{ \pm 6,72}$ & 0,2 & $80,7^{ \pm 7,57}$ & 0,2 \\
\hline$\Gamma: \Pi: \mathrm{T}-1: 1: 1$ & $56,5^{ \pm 3,98}$ & 4,2 & $58,3^{ \pm 4,16}$ & 4,3 & $62,4^{ \pm 5,56}$ & 4,3 \\
\hline$\Gamma: \Pi: \mathrm{T}-4: 4: 2$ & $58,9^{ \pm 4,04}$ & 3,7 & $59,4^{ \pm 4,78}$ & 4,1 & $62,6^{ \pm 6,78}$ & 4,2 \\
\hline$\Gamma: \Pi: T-5: 4: 1$ & $58,4^{ \pm 3,78}$ & 3,8 & $66,8^{ \pm 7,02}$ & 2,6 & $75,6^{ \pm 7,50}$ & 1,5 \\
\hline$\Gamma: \Pi: T-6: 3: 1$ & $70,8^{ \pm 7,12}$ & 1,3 & $71,3^{ \pm 6,89}$ & 1,6 & $73,8^{ \pm 6,74}$ & 1,9 \\
\hline
\end{tabular}

Примітки: $t_{0,001}=3,3 ; t_{0,01}=2,6 ; t_{0,05}=2,0 ; t_{0,1}=1,7$.

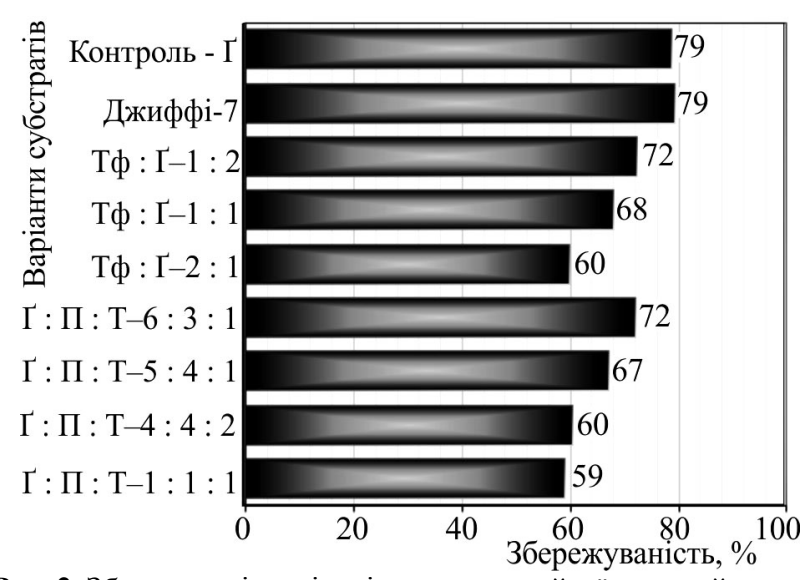

Рис. 2. Збережуваність сіянців сосни звичайної у контейнерах 3 різним складом субстрату (середнє за три роки досліджень)
Серед варіантів 3 використанням торфу у суміші із грунтом найвищу збережуваність сіянців $(72,4$ \%) встановлено при співвідношенні компонентів суміші Тф : $Г-1: 2$. Зі збільшенням частки торфу у суміші до $66 \%$ (Тф: Г - $2: 1$ ) збережуваність сіянців виявилася навіть меншою на 17,6 \%, ніж у варіанті використання суміші Тф: $Г-1: 1$, де цей показник нижчий за попередній варіант (Тф : Г- $1: 2$ ) на $6,3 \%$.

Отримані дані можна пояснити вищою (майже у 10 разів) вологомісткістю торфу (табл. 3), що сприяє більшому утриманню вологи у коренезакриваючій грудці субстрату, а згодом, у період зимового зберігання, призводить до вимерзання кореневих систем сіянців iз ЗКС, які перебували в умовах відкритого полігону впродовж зими - умовах, максимально наближених до умов подальшого росту на лісокультурних ділянках. 
Табл. 3. Результати фізичного та агрохімічного аналізів складових елементів субстратів, використаних для вирощування сіянців сосни звичайної у контейнерах

\begin{tabular}{|c|c|c|c|}
\hline Зразок & pH, вод. & pH, сол. & Вологомісткість, \% \\
\hline Грунт & 6,6 & 5,5 & 55,00 \\
\hline Перегній & 8,3 & 7,95 & 165,36 \\
\hline Тирса хв. порід & 3,9 & 3,22 & 312,00 \\
\hline Торф & 7,8 & 7,55 & 511,00 \\
\hline
\end{tabular}

Серед варіантів з використанням суміші грунту, перегною й тирси найменше значення показника збережуваності $(59,1 \%)$ виявлено у варіанті з найбільшим вмістом тирси $(\Gamma: \Pi: \mathrm{T}-1: 1: 1)$, а найбільше $(72,0 \%)-\mathrm{y}$ варіанті 3 найбільшою часткою грунту $(\Gamma: \Pi: \mathrm{T}-$ $6: 3: 1)$. Зі збільшенням частки перегною у суміші понад $40 \%$ спостерігалося пожовтіння хвої сіянців, утворювалося лужне середовище, що певною мірою пригнічувало ріст сіянців сосни звичайної.

Стан сіянців сосни за прийнятою для його оцінювання 4-бальною морфологічною шкалою (5 - відмінний, 4 - добрий, 3 - задовільний, 2 - незадовільний стан), порівняно 3 контролем, виявився найкращим у всіх торфовмісних варіантах (табл. 4).

Табл. 4. Стан однорічних сіянців сосни в контейнерах

\begin{tabular}{|c|c|c|c|}
\hline Варіант & Стан, бал & $t$ & $\begin{array}{c}\text { \% до кон- } \\
\text { тролю }\end{array}$ \\
\hline Грунт (контроль) & $4,2^{ \pm 0,14}$ & - & 100 \\
\hline $\mathrm{T} \phi: \Gamma-1: 1$ & $5,0^{ \pm 0,01}$ & 1,88 & 119 \\
\hline Тф: Г $-1: 2$ & $4,8^{ \pm 0,01}$ & 2,77 & 114 \\
\hline $\mathrm{T} \phi: \Gamma-2: 1$ & $4,3^{ \pm 0,02}$ & 1,92 & 102 \\
\hline Джиффі-7 & $4,5^{ \pm 0,03}$ & 0,69 & 107 \\
\hline Г:П:Т $-1: 1: 1$ & $4,4^{ \pm 0,67}$ & 1,73 & 105 \\
\hline Г:П:Т $-4: 4: 2$ & $4,2^{ \pm 0,27}$ & 3,31 & 100 \\
\hline Г :П:Т $-5: 4: 1$ & $4,5^{ \pm 0,12}$ & 2,01 & 107 \\
\hline Г:П:Т $-6: 3: 1$ & $4,8^{ \pm 0,07}$ & 2,63 & 114 \\
\hline
\end{tabular}

3 найвищою достовірністю $(\mathrm{P}>0,01)$ контрольні значення перевершили на 14 \% сіянці, що вирощувалися у варіанті субстрату Тф : Г - $1: 2$. Найменш ефективним 3 перевершенням контролю на $2 \%$ достовірно $(\mathrm{P}>0,1)$ виявився варіант 3 найбільшим вмістом торфу.

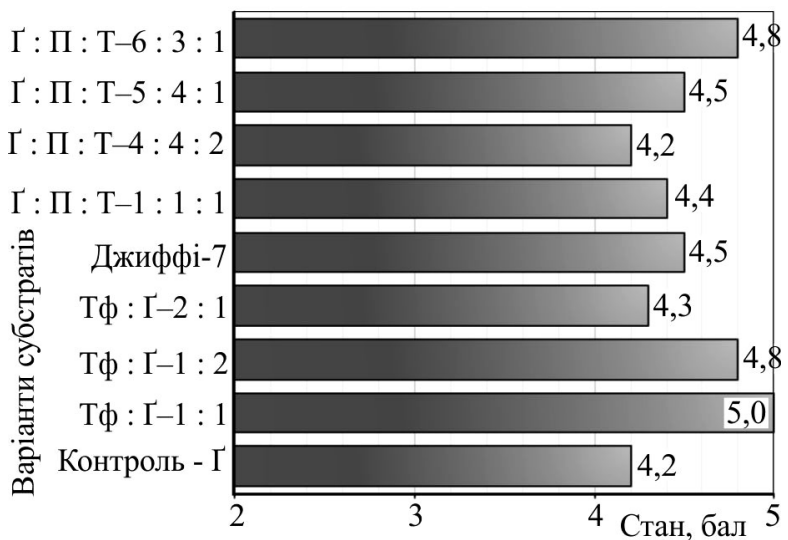

Рис. 3. Стан сіянців сосни звичайної у контейнерах з різним складом субстрату (середнє за три роки досліджень)

У варіантах субстрату з використанням грунту, перегною та тирси найкращий стан сіянців $(4,8)$ встановлено у варіанті Г : П : Т - $6: 3: 1$, який найбільш достовірно (P $<0,01)$ переважав контроль на 14 \% (рис. 3 ).

Обговорення отриманих результатів. Результати досліджень щодо визначення оптимального складу субстрату для вирощування сіянців сосни звичайної із закритою кореневою системою підтвердили, що найвищі значення схожості насіння сосни, подальша збережуваність сіянців впродовж їх вирощування та стан сіянців сосни виявилися у варіантах 3 використанням торфу Тф : Г - 2: 1 та у варіанті з використанням торфових таблеток Джиффі-7.

Високі показники схожості отримано і в варіантах 3 використанням трикомпонентних сумішей перегною, тирси та темно-сірого опідзоленого середньо суглинкового лісового грунту на лесах Г:П:Т $-5: 4: 1$ та Г : П : Т - $6: 3: 1$. Темно-сірі лісові опідзолені середньо суглинкові грунти на лесах за рівнем потенційної родючості $€$ одними 3 найродючіших грунтів України. Їх формування відбувалося під достатньо розрідженими широколистяними лісами 3 добре розвиненим трав'яним покривом на важко глинистих карбонатних лесах. Поєднання таких факторів грунтоутворення, як наявність значної кількості високо зольного органічного опаду, а також материнської породи, насиченої кальцієм та глинистими частками, надає темно-сірим опідзоленим грунтам високої поживної здатності.

Збережуваність та стан сіянців сосни звичайної у варіантах зазначених вище субстратів також мали високі якісні показники. Втім варто враховувати те, що порівняно 3 іншими субстратами, які використовували під час виготовлення сумішей для вирощування садивного матеріалу, лісовий грунт характеризується найвищим рівнем вмісту калію та фосфору. Винятком є тільки перегній, у якому вміст фосфору вищий за лісовий грунт, проте його кислотність $(8,3$ од. $\mathrm{pH})$, порівняно із грунтом (6,6 од. $\mathrm{pH}), \epsilon$ недостатньо сприятливою для вирощування садивного матеріалу більшості деревних порід, особливо хвойних. Відомо, що діапазон грунтової кислотності хвойних порід, за якої вони досягають високого рівня продуктивності, знаходиться в межах від слабо кислої (кислої) до нейтральної (слабо лужної). Саме такий рівень кислотності притаманний лісовому грунту (див. табл. 3).

Висновки. Внаслідок виконання дослідження було вивчено переваги та недоліки вирощування садивного матеріалу сосни в контейнерах. Було встановлено, що серед випробуваних субстратів при об'ємі контейнера $500 \mathrm{~cm}^{3}$ за комплексом переваг за досліджуваними показниками схожості, збережуваності та стану торфовмісний варіант із рівними частинами темно-сірого лісового середньо суглинкового опідзоленого грунту та торфу (Тф: Г - 1:1) та варіант трикомпонентної суміші Г : П : Т - $6: 3: 1 €$ найбільш збалансованими за основними грунтовими параметрами (кислотністю та вмістом поживних речовин) та найбільш оптимальними з досліджуваних для продуктивного росту сіянців сосни звичайної із закритою кореневою системою.

\section{References}

1. Belostotckii, N. N., Birtceva, A. A., \& Zhigunov, A. V. (1984). Assessment of the suitability of the substrate for growing planting material with closed roots. Metodicheskie ukazaniia. L.: LenNIILKh. [In Russian].

2. Dospekhov, B. A. (1985). Field experience methodology (with basics of statistical processing of research results. Moscow: Agropromizdat. [In Russian].

3. Hordiienko, M. I., Huz, M. M., Debryniuk, Yu. M. \& Maurer, V. M. (2005). Forest crops. Lviv: Kamula. [In Ukraine]. 
4. Huz, M. M. \& Huz, M. M. (2008). Current state and prospects of forest seedlings cultivation intensification. Scientific Bulletin of UNFU, 18(11), 84-92. [In Ukrainian].

5. Lialin, O. I. (2008). Weight and biometric parameters of two-year-old pine seedlings in containers. Forestry and Forest Melioration, 114, 287-294. [In Ukrainian].

6. Lialin, O. I. (2012). Improvement of technologies for growing pine and oak seedlings with closed root system in the conditions of the Left Bank Forest Steppe: Candidate dissertation for agricultural sciences (06.03.01 - Forest Plantation and Phytomelioration). Kharkiv, 20 p. [In Ukrainian].

7. Lialin, O. I. (2018). The influence of the substrate composition on the germination of pine seeds. Materialy Vseukrainskoi naukovopraktychnoi konferentsii "Kolesnikovski Chytannia". Kharkiv. HNUMG, 29-31 p. [In Ukrainian].
8. Maurer, V. M., \& Kaidyk, O. Yu. (2015). Reforestation of forests in Ukraine in the context of sustainable development: main problems and ways to solve them. Lisove $i$ sadovo-parkove hospodarstvo, 7. http://nbuv.gov.ua/UJRN/licgoc $2015 \quad 7 \_8$

9. Savushchyk, M. P., Maurer, V. M., Popov, M. Yu. \& Shuban, S. V. (2009). Modern technologies of forestry seed production and production of planting material. Naukovo- tekhnichna informatsiia: Derzhkomlishosp Ukrainy, part 1, 68 p. [In Ukrainian].

10. Tkach, V. P. (2012). Forests and forest cover of Ukraine: the current state and perspectives of development. Ukrainian Geographical Journal, 2, 49-55. [In Ukrainian].

11. Zhigunov, A. V. (2000). The theory and practice of growing planting material with a closed root system. St. Petersburg: SPbNIILKh. [In Russian].

O. I. Lialin', O. M. Tarnopilska', L. I. Tkach1, S. I. Musienko', V. V. Bondarenko²

${ }^{1}$ O. M. Beketov National University of Urban Economy, Kharkiv, Ukraine

${ }^{2}$ Ukrainian Research Institute of Forestry and Forest Melioration named after G. M. Vysotsky, Kharkiv, Ukraine

\section{GERMINATION, SURVIVAL RATE AND HEALTH OF SCOTS PINE (PINUS SYLVESTRIS L.) GROWN IN CONTAINERS}

In our experiments, we used a rigid container ("basket" type) $140 \mathrm{~mm}$ in high, $70 \mathrm{~mm}$ in average top diameter, with an effective volume of $500 \mathrm{~cm}^{3}$. A drainage hole of $6-7 \mathrm{~mm}$ in the diameter was made in the bottom of each container to remove excessive moisture from rainfall. A characteristic feature is that the containerized seedlings grew in open test sites with adjusted irrigation; the water input was 101 per $\mathrm{m}^{2}$ three times a week. The study on determining the optimal substrate composition for containerized Scots pine seedlings confirmed that the highest germination capacity of pine seeds and survival rate of seedlings during their cultivation as well as the best health of pine seedlings were registered in the peat-using variants, namely peat: soil = 2:1 mixture and in in the substrate variant with the use of Jiffy-7 peat pellets. High germination capacity was also noted in the variants using three-component mixtures with humus, sawdust and podzolic middle loamy dark gray wooded soil on loessial rocks, namely soil: humus: peat $=5: 4: 1$ and soil: humus: peat $=6: 3: 1$. In Ukraine, middle loamy dark gray wooded soil is among the most fertile ones by the level of potential fertility. The survival rate and health of Scots pine seedlings in the above substrate variants were also high. However, it should be considered that, compared to other substrates used in the mixtures for growing seedlings, the wooded soil has the highest potassium and phosphorus content. The only exception is humus. The phosphorus content in it is higher than in wooded soil, but its acidity (pH 8.3) as compared with the soil ( $\mathrm{pH} \mathrm{6.6)} \mathrm{is} \mathrm{not} \mathrm{sufficiently} \mathrm{favorable} \mathrm{for} \mathrm{the} \mathrm{growth} \mathrm{of} \mathrm{the} \mathrm{planting} \mathrm{stock} \mathrm{of} \mathrm{most} \mathrm{tree} \mathrm{species,} \mathrm{especi-}$ ally conifers. Among tested substrates for containers with a capacity of $500 \mathrm{~cm} 3$, the peat-containing variant with equal portions of middle loamy dark gray wooded soil and peat (peat: soil $=1: 1$ ) and the variant of the three-component mixture soil: humus: sawdust $=6: 3: 1$ are the most balanced in the basic soil parameters (acidity and nutrient content) and are the best among the studied ones for the productive growth of containerized Scots pine seedlings, considering germination capacity, survival rate, and health.

Keywords: Scots pine; substrate; closed root system; soil germination; state seedlings. 